\title{
Relations between rural development projects and urban migration: the Köykent Project in Turkey
}

\author{
Efeitos resultantes de projetos para o desenvolvimento rural na migração urbana: \\ o projeto Köykent na Turquia
}

\author{
Cihan Erdönmez ${ }^{I}$ Sezgin Özden ${ }^{\text {II }}$
}

\section{ABSTRACT}

In Turkey, migration from rural areas to the cities began in the 1950s. Although various rural development approaches were discussed in the 1960s and 1970s, none of them was successfully put into practice. In 2000, Köykent, one of these rural development approaches was started in the borough of Mesudiye. This study examines the effect of the Köykent Project on the migration from rural areas to cities. The results show that the project affected the migration in two ways. First, the tendency of rural residents to migrate to the cities decreased. Second, the tendency of urban residents, who had previously migrated from villages to cities, to return to their home villages increased.

Key words: Mesudiye, Turkey, rural urban migration, rural development, Köykent Project.

RESUMO

$\mathrm{Na}$ Turquia, a migração de áreas rurais para a cidade teve início na década de 1950. Embora várias abordagens tenham sido discutidas no sentido de desenvolver as zonas rurais, nos anos de 1960 e 1970, nenhuma dessas tentativas foi bem sucedida. Em 2000, foi implementado o Projeto Koykent no Município de Mesudiye. Esse estudo procurou examinar os efeitos do Projeto Köykent na migração de áreas rurais para as zonas urbanas. Os resultados mostraram que o projeto afetou a migração de duas formas. Primeiro, a tendência de migração das zonas urbanas para as zonas rurais diminuiu. Segundo, a tendência daqueles que residiam na zona urbana e que haviam migrado da zona rural foi de retornar ao seu lugar de origem.

Palavras-chave: Mesudiye, Turquia, migração urbana e rural, desenvolvimento rural, Projeto Köykent.

\section{INTRODUCTION}

Rural development can be characterized as the process of achieving desired futures in the countryside (ELANDS \& WIERSUM, 2001). Although there are many risk factors that must be considered when undertaking rural development (ANDERSON, 2003; KOSTOV \& LINGARD, 2003), substantial success has been achieved in some rural areas described as having affirmative conditions during recent decades (RUBEN \& PENDER, 2004). However, similar successes can't be easily realized in areas that are constrained by natural resources, geographical characteristics, and social structures, among others. In cases like these, the intent of rural development is to extend the renewal of rural institutions, procedures and culture, and their impact on the rural space (ELANDS \& WIERSUM, 2001). One of the typical results of insufficient rural development in such places is migration from rural to urban areas. Rural out-migration causes many problems for these settlement areas. Yet, the most important problem is the loss of labour. As people leave for cities, it becomes impossible to take care of agricultural fields or to find workers for forestry jobs. Since agriculture and husbandry are still vital parts of the Turkish economy, this trend causes increase in the agricultural products price on the one hand, as rural places lose population. On the other hand, decreasing agricultural production results in an increase in the share of agricultural products among overall imports (ÖZDEN \& MENDES, 2005).

\footnotetext{
Istanbul University Faculty of Forestry, Department of Forest Policy and Administration, 34473 Bahcekoy/Istanbul/Turkey. Email: erdonmez@istanbul.edu.tr. Corresponding author.

IICankiri Karatekin University Faculty of Forestry, Department of Forest Economics, 18200, Cankiri-Turkey.
} 
As in much of the developing world, migration also has been one of main problem in rural parts of Turkey since 1950's. During the period 19531957 only, a million farmers were dislocated (TAS \& LIGHTFOOT, 2005) and the result of in-migration to urban areas was unplanned urbanization.

Throughout the Ottoman period, agriculture was maintained by simple technologies. The relationship between state and peasant never moved beyond tax and recruitment proceedings (GERAY, 1974). There were many people in Anatolia who migrated from rural to urban, from rural to rural, and from urban to urban (GÜMÜSÇÜ, 2004). During the period in which the Turkish Republic emerged, the country's rural areas and their social structure were at a low point in most areas. In the years following the Republic's founding (1923) significant importance was placed on industry, yet the country maintained its existence as a farming society for many years. Atatürk, the founder of the Republic, and his staff gave much attention to farming by first issuing the Village Law in 1924, which accomplished much in the way of the needed changes to the rural social structures. Many of the resulting changes and projects were successful until the 1940's, when they became a subject of political conflicts in the shift to the multi-party regime (1946). During this period many of the scientific principles upon which Atatürk had based his changes were lost. For instance, political clashes led to the closing of the "Village Institutes" that had been developed in the 1930's and had been used by the United Nations as a model for similar countries (TÜTENGIL, 1975).

There have not been many popular policies in Turkey related to rural development (MARIN, 2005). In the third Five-Year Development Plan covering the years 1973-1977, two important new approaches to rural development were introduced. One was the Central Villages and the other was the Köykent Project.

Central Villages describes an approach in which the public services were aggregated in particular rural centers, which were intended to give provision to the surrounding villages. Thus, dispersed villages were integrated with one another through a more rational hierarchy of public service provision. That is, the redistribution of basic needs was more efficiently met by creating new intermediate rural centers (KeskInok, 2006). Despite the fact that the Central Villages Approach was valuable in theory, the economic aspects of rural development were neglected. Whereas rural problems in Turkey include physical, social, and economic aspects, the Central Villages Approach focused only on organizational aspects, thus ignoring these problems and resulting in failure (GÜVEN, 1996).
On the contrary, Köykent Approach has more rational and holistic characteristics by including economic aspects (ERDÖNMEZ, 2005).

While Central Villages Approach was never realized in practice, the Köykent idea was implemented in two different regions during those years, one in the Western Black Sea and the other in Eastern Anatolia. However, it could not be continued because of social and political instabilities. Thus, they were not completed and the results of these projects could not be obtained or evaluated.

The Köykent Project is focused on maintaining the rural population in particular places and reversing the rural-to-urban migration process by remedying social, economical and physical problems. A 1973 Ministry publication spelled out the purpose of the Köykent Approach through three specific goals (YAVUZ \& KELES, 1983):

(i) To meet the needs of rural populations through minimal personnel and low levels of investment. For example, the project would provide health and education services, infrastructure, etc.

(ii) To create job opportunities for the unemployed population, thereby helping to reduce the pressures caused by rapid population growth. Here, the government focused on efforts that were aimed at increasing agricultural productivity and development of small- and medium-scale forestry and agriculture industries.

(iii) To manage urbanization in a reasonable way by preventing the rapid growth of population masses around big cities that were experiencing flows of rural migrants to newly created job opportunities in the cities.

The Mesudiye Köykent Project began in 2000 and was completed by 2003. The purposes of the Mesudiye Köykent Project were to provide basic services to be delivered to the villages in a planned way by establishing co-operation and coordination between the villages within the scope of the village cluster formed and to provide a healthier system of development. On the other hand, The Mesudiye Köykent Project aimed to restore the peasant to urban facilities without causing loses in their living location in the village and reversing heavy migration by creating alternative job opportunities for both people who still live in the villages and those who intend to return to their villages. Additionally, The Mesudiye Köykent Project focused on regenerating unused natural resources (agricultural lands, pastures, etc) for the region's and country's economy with the help of innovative investments and providing public participation in project planning and thus bring democratic operability to the project. 
This study examines the short-term effect of the Köykent Project on migration from the rural to the urban areas. Using data from a questionnaire, it was asked how the Köykent Project has effected the migration from rural areas to the cities. The migration in this area appears in two forms. First, the project appears to increase or decrease the tendency of the population already living in the project area to migrate to the cities. Second, the project increases or decreases the tendency of those people who migrated in the past from the project area to migrate back to their villages. The main aim of this study is to verify whether Köykent Project has effected the migration from rural areas to the cities.

\section{MATERIAL AND METHODS}

The Project was implemented in Mesudiye, which is located in the province of Ordu. Despite the fact that the district is located in the Eastern Black Sea, its geographic features form a transit zone between the Black Sea and Central Anatolia. Mesudiye is located south the province centre, $120 \mathrm{~km}$ via the highway from the sea.

A number of researchers have observed that Mesudiye is composed of a flexible population and a social structure that is open-minded and that a considerable part of the population makes use of the social security services. By contrast, there are severe bottlenecks in the usage of credits for agricultural purposes, while the industry and service sectors are almost non-existent. At the same time, the productivity of forestry resources and the biological diversity comprise superior features of the area. Given these acquired natural and cultural values, especially for tourism in rural areas in the district, there is potential for development on a medium- and long-term basis (ÜSTÜNDAG, 2000; GÜLÇUBUK, 2000; COSGUN, 2000; GÜNDOGDU, 2000; AÇIKSÖZ, 2000).

Although the district has a rather old settlement area and harbors an ancient cultural structure, it began to experience serious migrationrelated population losses in the 1960s, primarily because of economic deficiencies. A major part of this exodus gravitated to big cities, such as Istanbul and Ankara, and destinations abroad, primarily to Germany. In 1960, the population of Mesudiye started to decline, while the populations of Ordu province, the Black Sea Region and Turkey as a whole continued their growing trend. The decrease in Mesudiye was especially high in 1980-1990, indicating the exodus that took place in the district.
In order to study the short-term effect of the Köykent Project on the migration from the rural to the urban areas, rely on four different data relied on four different sources. First, relied on interviews with 200 household heads presently living within the project villages as well as outside the project areas in 2003. Interviewees were selected in village lists randomly. Their tendencies with respect to migration to the cities were determined and these tendencies compared with each other. Second, it was interviewed 278 household heads who migrated in the past from the villages within and outside the project areas to Turkish cities in 2003. These respondents were also selected randomly from among registered member lists of societies of Mesudiye in the provinces of Ankara, Ordu, Niksar and Antalya. It was asked them about their future plans to return to their villages, and notes were took of any tendency towards a return to their villages in future and these tendencies were compared with each other. All interviews, both in the villages and in the cities were done by face to face meeting and consequently some interviewees whose characteristics were considered as not adequate to be a representative were eliminated. Third, social data were obtained for all villages within the project area. This information included X, Y, Z. For specific areas, it was selected villages outside the project area which were under similar social and natural circumstances to the project villages and compared these with project villages. Fourth, it was visited villages both within and outside the project area in the borough of Mesudiye from April 2002 to August 2004 to observe individual situations. The primary questionnaire data was analyzed using chi-square analysis to compare the tendencies related to project villages to the tendencies related to the other villages. Because interviewees were selected from among household heads and over $90 \%$ of interviewees both in the villages and in the cities were male it could not be possible to compare the tendencies of male population to the tendencies of female population.

\section{RESULTS}

In this section, e the effect of the Project on the migration from the rural to the urban areas was examined, by examining differences in the tendency of those people living in the project villages with those living in the villages outside the project area to migrate to cities.

Table 1 illustrates the significant difference between those people living in project villages and in those living in villages outside the project to declare intent to migrate to cities. While $25 \%$ of those living in 
Table 1 - Migration tendency of villagers to the cities in Mesudiye in 2003.

\begin{tabular}{|c|c|c|c|c|c|c|c|c|c|}
\hline & \multicolumn{4}{|c|}{-----------------will migrate to city---------------- } & \multicolumn{2}{|c|}{-------will not------- } & \multirow{3}{*}{ Total } & \multirow{3}{*}{$X^{2}$} & \multirow{3}{*}{$p$} \\
\hline & \multicolumn{2}{|c|}{------in 10 years------- } & \multicolumn{2}{|c|}{----after 10 years---- } & \multirow{2}{*}{$\mathrm{n}$} & \multirow{2}{*}{$\%$} & & & \\
\hline & $\mathrm{n}$ & $\%$ & $\mathrm{n}$ & $\%$ & & & & & \\
\hline Village groups & & & & & & & & & \\
\hline Project villages & 18 & 18 & 7 & 7 & 75 & 75 & 100 & & \\
\hline Other villages & 31 & 31 & 15 & 15 & 54 & 54 & 100 & 9.774 & 0.01 \\
\hline Age groups & & & & & & & & & \\
\hline Young & 30 & 65 & 11 & 24 & 5 & 11 & 46 & & \\
\hline Middle & 12 & 21 & 7 & 12 & 38 & 67 & 57 & & \\
\hline Old & 4 & 4 & 1 & 1 & 92 & 95 & 97 & 89.984 & 0.001 \\
\hline Education level & & & & & & & & & \\
\hline Elementary & 11 & 11 & 13 & 13 & 74 & 76 & 98 & & \\
\hline Middle-High & 35 & 34 & 6 & 6 & 61 & 60 & 102 & 17.793 & 0.001 \\
\hline Income level & & & & & & & & & \\
\hline Low & 22 & 20 & 9 & 8 & 79 & 72 & 110 & & \\
\hline Middle & 24 & 27 & 10 & 11 & 56 & 62 & 90 & 2.380 & $<0.05$ \\
\hline
\end{tabular}

the project villages planned to migrate to the city, $18 \%$ within 10 years and $7 \%$ after 10 years, these rates were higher in the project-excluded villages: $31 \%, 15 \%$ and $46 \%$ respectively. Without a doubt, the village of residence is not the only factor affecting the tendency of migration from the villages to the cities.

Age also plays an important role in the tendency of emigration to the cities. The tendency towards migration to the city is higher in younger groups. A similar relationship can also be observed between the educational level and the tendency to migrate. Yet, the increase in the tendency towards migration to the city, in contrast to the increase in the education level, is not as evident in these age groups. At the same time, no significant relationship between the income level and the tendency towards migration to the cities could be observed.

On the other hand, it was explored whether the Köykent Project had any effect on the migration tendencies of those people who formerly migrated from Mesudiye to the cities and are presently living in the cities to return to their villages. It is useful to analyze table 2 to determine the tendency of this group, which is presently living in the cities, to return to their villages and to understand whether the Köykent has any effect on such a tendency.

There is a significant difference between those who settled in the city from project villages and those who settled from villages not included in the project in the tendency to return to villages. While $40 \%$ within 10 years, and $38 \%$ after 10 years, $78 \%$ of the people who migrated from the project villages think of going back to their villages in the future, $56 \%$ of those having migrated from outside the project think of returning.

With regards to the tendency to return to the villages, a greater difference can be observed after 10 years. This situation suggests that the age factor may have an effect on the tendency of individuals to return to their village. In fact, the tendency of the middle age group to return to the village is significantly higher than for both the younger and older groups. While the tendency to return to the villages by the younger group shows an increase after 10 years, this tendency gains greater importance for the middle and older age than within 10 years. At the same time, another factor that has significant effect on the tendency of city people to move back to the villages is the education level. From this point of view, the tendency of elementary school graduates is greater than that of middle and high school graduates. On the other hand, no significant relationship could be found between the tendency of returning back to the village and the income level.

The probable short-term effects of the project, which was started in 2000 and completed in 2003, already were measurable at the end of this period. The changes that occurred were noted by comparing some of the factors that form the foundation of the rural structure, such as population and agricultural holdings, both before and after the project, are shown. These same factors, before and after, were also monitored for non-project villages and efforts were made to understand whether there is a difference between project villages and villages outside the project. The findings regarding the matters in question are reflected in figure 1.

Ciência Rural, v.39, n.6, set, 2009. 
Table 2- Return tendency of city residents migrated from Mesudiye to their villages in 2003.

\begin{tabular}{|c|c|c|c|c|c|c|c|c|c|}
\hline & \multicolumn{4}{|c|}{-------------will come back to village------------- } & \multicolumn{2}{|c|}{------will not------ } & \multirow{3}{*}{ Total } & \multirow{3}{*}{$X^{2}$} & \multirow{3}{*}{$p$} \\
\hline & \multicolumn{2}{|c|}{------in 10 years------ } & \multicolumn{2}{|c|}{------after 10 years----- } & \multirow{2}{*}{$\mathrm{n}$} & \multirow{2}{*}{$\%$} & & & \\
\hline & $\mathrm{n}$ & $\%$ & $\mathrm{n}$ & $\%$ & & & & & \\
\hline Village groups & & & & & & & & & \\
\hline Project villages & 25 & 40 & 24 & 38 & 14 & 22 & 63 & & \\
\hline Other villages & 68 & 31 & 53 & 25 & 94 & 44 & 215 & 10.978 & 0.005 \\
\hline Age groups & & & & & & & & & \\
\hline Young & 19 & 19 & 31 & 31 & 49 & 50 & 99 & & \\
\hline Middle & 67 & 43 & 43 & 27 & 47 & 30 & 157 & & \\
\hline Old & 7 & 32 & 3 & 14 & 12 & 54 & 22 & 30.641 & 0.001 \\
\hline Education level & & & & & & & & & \\
\hline Elementary & 27 & 58 & 10 & 21 & 10 & 21 & 47 & & \\
\hline Middle-High & 37 & 28 & 40 & 30 & 56 & 42 & 133 & & \\
\hline University & 29 & 30 & 27 & 27 & 42 & 43 & 98 & 14.377 & 0.01 \\
\hline Income level & & & & & & & & & \\
\hline Low & 46 & 41 & 31 & 28 & 35 & 31 & 112 & & \\
\hline Middle & 37 & 31 & 28 & 23 & 55 & 46 & 120 & & \\
\hline High & 10 & 22 & 18 & 39 & 18 & 39 & 46 & 9.961 & 0.05 \\
\hline
\end{tabular}

The change in the overall permanent population may be negligible. While the permanent population living in the project villages was 1,630 , it increased to 1,650 after the project. In contrast, the permanent population of the villages selected outside the project villages decreased in the same period from 3,275 to 2,795 (i.e. a decrease of $15 \%$ ). Additionally, while an increase of $24 \%$ in the seasonal population (population that lives especially in the summer months in their villages and spends the winters in the cities) has taken place in the project villages; only an increase of five percent in the villages outside the project was recorded. Looking at the present agricultural holdings, against an increase of five percent in the project villages, a decrease of seven percent can be seen in the villages excluded from the project.

One of the most remarkable differences noticed between the project villages and non-project villages is related to the cattle number. While the cattle number had increased at a rate of $16 \%$ in the project villages, a decrease of $31 \%$ was recorded in the nonproject villages. On the other hand, an ocular decrease has taken place in both groups with regard to the number of small cattle. The yearly increase in housing

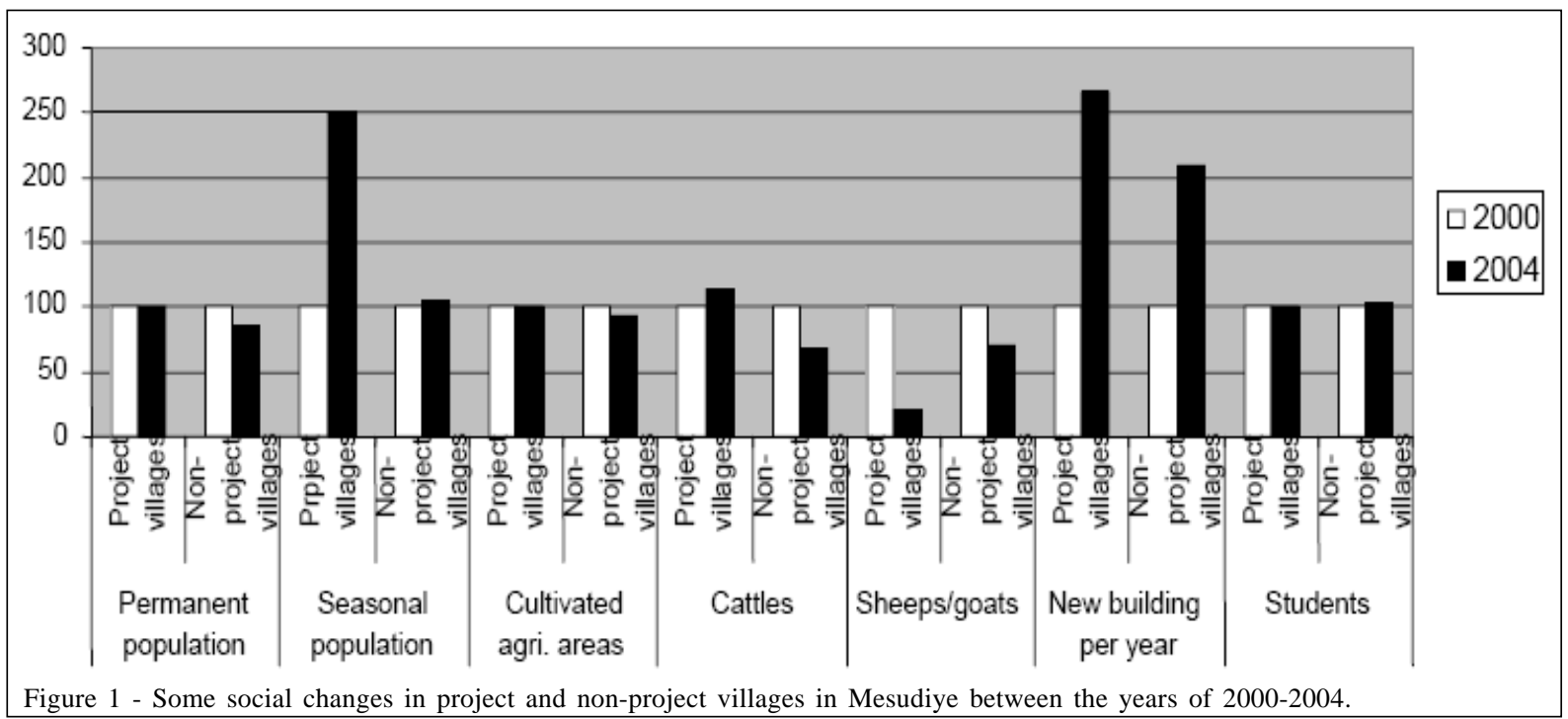

Ciência Rural, v.39, n.6, set, 2009. 
construction was $236 \%$ in the project villages and $108 \%$ in the villages outside the project area. The imbalance between such a high increase in the number of new houses and the population growth is a matter that relates to traditional social values. A similar tendency can be observed countrywide in Turkey. People who spend only one week a year in their villages or even those who come to their villages only once every few years may have also built a house there. The most negative result noted in the comparison between project villages and non-project villages is the decrease in the number of students. Thus, a decrease of 34\% took place in the project villages, whereas the number of students increased three percent in the non-project villages.

\section{CONCLUSIONS}

Similar to many other developing countries, rural to urban migration constitutes a serious problem in Turkey, given the difficulties faced in rural areas and the attractiveness of urban areas for jobs. The most effective way to prevent this type of migration is the implementation of rural development projects that take advantage of endemic characteristics. The Köykent Project established and implemented in 2000-2003 constitutes the final ring in the historical progress of rural development.

There is no doubt that more time is needed in order to understand whether such a large-scale goal has been successful or not. Nevertheless, to review some of the short-term results of the project may indicate the final results. As a result of observations made in this project, it was shown that the Köykent Project influenced the migration of people from these villages to the cities. This effect is visible both in the decrease of the tendency of people presently living in the project villages to move to the cities and the increase in the tendency of those people having moved to the cities from the project villages to return. In addition, concrete progress has been made in some matters such as permanent and seasonal population, agricultural holdings, etc. in the project villages when comparing them to the time before the project. Taken together, these findings are clear signs that the project has had an influence on the migration from the villages to the cities. Still, important questions remain unanswered. First, how will these effects, which have been observed in a short time, play out over the middle- and longerterm? Time is needed to answer this question. Second, to what extent is this level of development sufficient to apply it to the rest of Turkey and how might this be best accomplished? More intensive research and more consistent development policies are necessary in order to answer these questions.

\section{ACKNOWLEDGEMENTS}

We deeply thank Dr. Patrick T. Hurley from Department of Political Science, College of Charleston, for his excellent comments on previous versions of this paper. He helped us clarify our comments significantly and very much improved the document. Funding support from Istanbul University Research Fund (Project №. 1482/28082000) is gratefully acknowledged.

\section{REFERENCES}

AÇIKSÖZ, S. Mesudiye'de turizm potansiyeli (Tourism potential in Mesudiye). In : EKSI, A. Mesudiye ilcesi gelisme plani (Development Plan of Mesudiye District). Ankara: Turkiye Kalkinma Vakfi, 2000. p.277-294.

ANDERSON, J.R. Risk in rural development: challenges for managers and policy makers. Agricultural Systems, v.75, p.161-197, 2003.

BaSa, S. Ordu Mesudiye ilcesi Cavdar ve yoresi koyleri köykent projesi (Köykent Project of Çavdar and neighbourhood villages of Mesudiye district, Ordu). Mesudiye: Mesudiye Kaymakamligi, 2000. 15p.

COSGUN, U. Mesudiye'de dogal kaynaklar (Natural resources in Mesudiye). In: EKSI, A. Mesudiye ilcesi gelisme plani (Development Plan of Mesudiye District). Ankara: Turkiye Kalkinma Vakfi, 2000. p.203-236.

ELANDS, B.H.M.; WierSUM, K.F. Forestry and rural development in Europe: an exploration of socio-political discourses, Forest Policy and Economics, v.3, p.5-16, 2001.

ERDÖNMEZ, C. Köykent: olumlu ve olumsuz yönleriyle bir kirsal kalkinma projesinin çözümlemesi (Köykent: An analysis of a rural development project with its positive and negative dimensions), Süleyman Demirel Üniversitesi Orman Fakültesi Dergisi. Faculty of Forestry Journal, v.A2, p.35-51, 2005.

GERAY, C. Planli dönemde köye yönelik çalismalar: Sorunlar, yaklasimlar, örgutlenmeler (Movements focused on the villages in planned age: Problems, approaches, organizations). Ankara: Turkiye Ortadogu Amme Idaresi Enstitusu, 1974. 408p..

GÜLÇUBUK, B. Mesudiye'de tarimsal krediler (Agricultural credits in Mesudiye). In : EKSI, A. Mesudiye ilcesi gelisme plani (Development Plan in Mesudiye District). Ankara: Turkiye Kalkinma Vakfi, 2000. p.147-174.

GÜMÜSÇÜ, O. Internal migration in sixteenth century Anatolia. Journal of Historical Geography, v.30, p.231-248, 2004.

GÜNDOGDU, G. Mesudiye'de sanayi ve hizmetler (Industry and services in Mesudiye). In : EKSI, A. Mesudiye ilcesi gelisme plani (Development Plan in Mesudiye District). Ankara: Turkiye Kalkinma Vakfi, 2000. p.237-276, 2000.

GÜVEN, S. Turkiye'de sosyal sorunlar ve sosyal politikalar (Social problems and social policies in Turkey). Istanbul: Ezgi Kitabevi Yayinlari, 1996. 491p. 
KESKINOK, C. Opportunities for Integration: the Turkish case: return to villages and rehabilitation project, cities between integration and disintegration: opportunities and challenges. Sitges: International Society of City and Regional Planners (ISoCaRP), 2006. p.98-113.

KOSTOV, P.; LINGARD, J. Risk management: a general framework for rural development. Journal of Rural Studies, v.19, p.463-476, 2003.

MARIN, M.C. A retrospective view of the Turkish rural urban development policies and the case of the Village Towns. Urban Policy and Research, v.23, p.497-518, 2005.

ÖZDEN, S.; MENDES, M. The usage of multiple correspondence analysis in rural migration analysis. A Mediterranean Journal of Economics, Agriculture and Environment, v.4, p.36-41, 2005.
RUBEN, R.; PENDER, J. Rural diversity and heterogeneity in less-favoured areas: the quest for policy targeting. Food Policy, v.29, p.303-320, 2004.

TAS, H.I.; LIGHTFOOT, D.R. Gecekondu settlements in Turkey: rural-urban migration in the developing European periphery. Journal of Geography, v.104, p.263-271, 2005.

TUTENGIL, C.O. 100 soruda kirsal Türkiye’nin yapisi ve sorunlari (Structure and problems of rural Turkey in 100 questions). Istanbul: Gercek Yayinevi, 1975. 255p.

ÜSTÜNDAG, N. Mesudiye'de sosyal ve kulturel yapi (Social and cultural structure in Mesudiye). In: EKSI, A. Mesudiye ilcesi gelisme plani (Development Plan in Mesudiye District). Ankara: Turkiye Kalkinma Vakfi, 2000. p.65-106.

YAVUZ, F. ; KELES, R. Çevre sorunlari (Environmenta problems). Ankara: Ankara Üniversitesi, 1983. 320p. 